\title{
Uma teoria para as formas e forças próprias da imaginação simbólica
}

Ana Taís Martins Portanova Barros

Pós-doutora; Universidade Federal do Rio Grande do Sul, Porto Alegre, RS, Brasil

anataisportanova@icloud.com

DURAND, Gilbert. Les structures anthropologiques de l'imaginaire. Paris: Dunod, 2016.

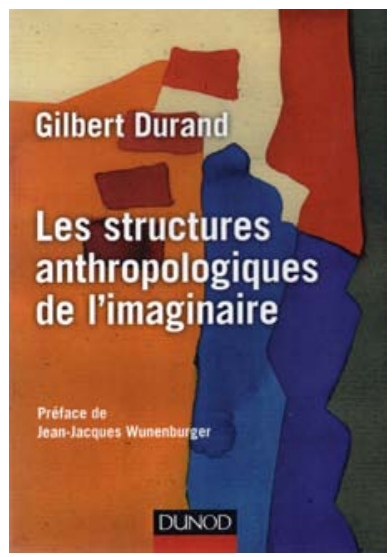

A Teoria Geral do Imaginário não é popular, pelo contrário: hermética, complexa, chega mesmo a exigir erudição. No entanto, não é difícil encontrar nas pesquisas, por ela embasadas, apropriações estapafúrdias que ignorem sua sutileza e descambem em esquematismos herdeiros, do mais pobre estruturalismo até impressionismos infantilmente acríticos. É aí, que entra a crítica de Jean-Jacques Wunenburger, em 2015, no encerramento do II Congresso Internacional do Centre de Recherhes Internationales sur l'Imaginaire (CRI2i), em Porto Alegre: "Nós, durandistas, somos os piores detratores de Gilbert Durand”. Como remédio, o retorno constante à fonte, não para erigi-la em lei, manifesta nos nefastos argumentos de autoridade, mas para dela extrair novas aberturas, como é possível e desejável com as obras verdadeiramente férteis. Daí, a relevância da nova edição de As estruturas antropológicas do imaginário, a 12ª lançada na França, que celebrou, em 2016, os 50 anos da Teoria Geral do Imaginário de Gilbert Durand.

Durand morreu em dezembro de 2012, e o filósofo Jean-Jacques Wunenburger foi escolhido para escrever o prefácio dessa que é a primeira edição da obra após o 
desaparecimento do autor. Tal escolha não poderia ser mais justa e feliz: Wunenburger não só é um filósofo que interpreta Durand de modo excepcional, como também leva adiante suas proposições, fá-las frutificar em sua própria obra sem cair no arremedo redutor ou na metáfora generalizada.

Na França dos anos 1960, quando As estruturas antropológicas do imaginário foi publicado, pela primeira vez, os autores em evidência na rive gauche seguiam Descartes, Hegel, Marx e Freud. 0 estruturalismo estava na moda, e sentindo-se provocado a dar uma resposta a As estruturas elementares do parentesco, de Lévi-Strauss, Durand colocou, em sua tese, o título de As estruturas antropológicas do imaginário. A intenção era boa: terminar com a infindável disputa entre o estruturalismo e a hermenêutica, propondo um estruturalismo figurativo, de formas dinâmicas. No entanto, isso não impede que os leitores ligeiros de Durand vejam na sua obra determinismo e esquematismos.

0 que são, então, essas estruturas figurativas? São maneiras que a imaginação tem de organizar as imagens simbólicas, entendidas como profundamente (ou seja, arquetipalmente) motivadas e, aí sim, culturalmente determinadas. Ora, nem a incontornabilidade arquetipal, nem a determinação cultural são fixas; elas estão situadas em polos extremos do imaginário, ambos lutando por se instalar na consciência antropológica. A arquetipia e a fenotipia criam entre si um trajeto no qual as imagens movimentam-se, chamado por Durand de trajeto antropológico ou trajeto do sentido. 0 modo que essas imagens organizarem-se, nesse movimento, resulta em estruturas que, por serem determinadas pelas próprias imagens, são chamadas de figurativas.

As ideias de Durand foram adotadas, em grande parte, por estudos da Literatura, mas logo foram espraiadas para as Artes, a Antropologia e a Filosofia. No Brasil, a Teoria Geral do Imaginário foi introduzida pela pesquisadora franco-brasileira, Danielle Perin Rocha Pitta, na Universidade Federal de Pernambuco (UFPE), na área de Antropologia, nos anos 1970. Diferentemente da Europa, por aqui, a área que mais trabalha com a teoria é a da Educação, na qual são pioneiros José Paula Carvalho e Maria Cecília Sanchez Teixeira, da Faculdade de Educação, da Universidade de São Paulo (USP). A Comunicação vem dando alguma atenção à Teoria Geral do Imaginário há pouco mais de uma década, quando nós mesmos defendemos tese de doutoramento, com essa base, junto à Escola de Comunicações e Artes da USP, muito embora, a palavra "imaginário" já figurasse em trabalhos anteriores na área, mas sem uma definição operacional e sem o mergulho arquetipológico durandiano. 
No Brasil, a obra recebeu quatro edições, todas pela Martins Fontes e todas esgotadas. As três primeiras têm tradução de Helder Godinho. A mais recente é de 2012, com tradução de Karina Jannini. Em todas as edições brasileiras (DURAND, 1997; 2001; 2002, 2012) ocorrem duas imprecisões que podem interferir na compreensão de certas passagens. A primeira, refere-se aos vocábulos franceses schéma e schème. Enquanto o primeiro pode ser confortavelmente traduzido por esquema, o segundo indica, segundo o próprio Durand (2016, p. 40), “[...] a factividade e a não substantividade geral do imaginário",1 próximo ao que Bachelard chama de símbolo motor: "Faz a junção, não mais como queria Kant, entre imagem e conceito, mas entre os gestos inconscientes da sensóriomotricidade, entre as dominantes reflexas e as representações." (DURAND, 2016, p. 40). ${ }^{2}$ Não há, na língua portuguesa, uma palavra que traduza adequadamente esse sentido. Teria sido preferível mantê-la em francês na edição brasileira, mas ela foi traduzida também por esquema, como se Durand a tivesse usado indiferentemente a schéma - o que não é o caso. A segunda imprecisão refere-se à palavra synthème, extrapolando o sentido que o dicionário francês traz para esse vocábulo (de unidade sintática mínima em um enunciado) e parafraseando Lévi-Strauss com seu myhtème, Durand designa por synthème, os sintomas sociais do mito, manifestações dele na superfície dos fenômenos. Em vez de ser traduzido por sintema que, em português, tem sentido similar ao francês, esse vocábulo foi traduzido como sistema, o que se afasta muito do sentido original. Esses erros podem afetar, consideravelmente, a compreensão de um conteúdo que, em si, é bastante complexo; assim, espera-se que sejam corrigidos em uma nova edição brasileira da obra.

Além de evitar interpretações equivocadas, por conta dos problemas de tradução, a leitura dessa nova edição francesa vale pelos prefácios que a acompanham, especialmente, os da 11a e 10aㅡ edições (DURAND, 1982; 1983), nos quais Durand fala sobre as modificações que faria se escrevesse a tese (DURAND, 2016). A 12ª edição, agora lançada, é indispensável, também, por seu prefácio inédito, em que Jean-Jacques Wunenburger (2016) situa a obra de Durand em um contexto histórico, esclarece suas escolhas epistemológicas, mapeia a recepção de seu trabalho e arrisca-se, até mesmo, a falar do futuro do durandismo. Que esse seja longo e frutuoso.

\footnotetext{
${ }^{1}$ No original francês: “[...] la factivité et la non-substantivité générale de l'imaginaire.” (DURAND, 2016, p. 40).

2 No original francês: "Il fait la jonction, non plus comme le voulait Kant, entre l'image et le concept, mais entre les gestes insconscients de la sensori-motricité, entre les dominantes réflexes et les representations." (DURAND, 2016, p. 40).
} 


\section{Referências}

DURAND, Gilbert. As estruturas antropológicas do imaginário: introdução à arquetipologia geral. Tradução de Helder Godinho. São Paulo: Martins Fontes, 1997.

DURAND, Gilbert. As estruturas antropológicas do imaginário: introdução à arquetipologia geral. Tradução de Helder Godinho. 2. ed. São Paulo: Martins Fontes, 2001.

DURAND, Gilbert. As estruturas antropológicas do imaginário: introdução à arquetipologia geral. Tradução de Helder Godinho. 3. ed. São Paulo: Martins Fontes, 2002.

DURAND, Gilbert. As estruturas antropológicas do imaginário: introdução à arquetipologia geral. Tradução de Karina Jannini. 4. ed. São Paulo: Martins Fontes, 2012.

DURAND, Gilbert. Les structures anthropologiques de l'imaginaire. Introduction a l'archétypologie générale. 10. ed. Paris: Dunod, 1982.

DURAND, Gilbert. Les structures anthropologiques de l'imaginaire. Introduction a l'archétypologie générale. 11. ed. Paris: Dunod, 1983.

DURAND, Gilbert. Les structures anthropologiques de l'imaginaire. Introduction a l'archétypologie générale. 12. ed. Paris: Dunod, 2016.

WUNENBURGER, Jean-Jacques. Préface à la nouvelle édition. In: DURAND, Gilbert. Les structures anthropologiques de l'imaginaire. Introduction à l'archétypologie générale. Paris: Dunod, 2016. p. V-XXII. 